\title{
ERRATA
}

\section{Procedures Involving Liquid Media for Detection of Bacterial Contamination in Breweries}

\author{
H. J. J. VAN VUUREN, H. A. LOUW, M. A. LOOS, AND R. MEISEL
}

Department of Microbiology and Virology, University of Stellenbosch, Stellenbosch, 7600, South Africa, and

Central Laboratory, South African Breweries, Isando, 1600, South Africa

Volume 33, no. 2, p. 247, column 2, line 3: "Comparison of UL, YWS, UL plus LPL, ..." should read "Comparison of UL, YWS, UL plus LP ..."

Page 248, Table 1: Column heading "Known contaminated samples detected with UL + $\mathrm{LP}^{b}(\%)$ " should read "Known contaminated samples detected with UL + LP ${ }^{a}(\%)$."

\section{Occurrence of Escherichia coli in Wild Cottontail Rabbits}

\author{
R. KOZLOWSKI, P. J. GLANTZ, AND R. G. ANTHONY
}

Department of Veterinary Science and School of Forest Resources, The Pennsylvania State University, University Park, Pennsylvania 16802

Volume 33, no. 3, p. 563: The last sentence of the abstract should read, "Four serogroups $(\mathrm{O} 7, \mathrm{O} 77, \mathrm{O} 73$, and $\mathrm{O103})$ were predominant among the isolates and were considered resident coliflora of this species of cottontail rabbits." 